\title{
Paradigma baru penggunaan statin: efek kardioprotektif atau penyebab onset baru diabetes melitus?
}

\author{
Gede Bangun Sudrajad ${ }^{1}$, Armi Setia Kusuma ${ }^{2}$, Rina K. Kusumaratna ${ }^{3}$
}

\begin{abstract}
ABSTRAK
3-Hydroxy-3-methylglutaryl coenzyme A (HMG-CoA) reductase inhibitors atau yang biasa disebut sebagai statin, merupakan obat yang sudah digunakan sejak 30 tahun silam dan merupakan salah satu obat yang paling sering digunakan untuk terapi dislipidemia. Menurut hasil terbaru dari banyak studi observasional, randomized controlled trials (RCTs) dan meta-analyses telah mengonfirmasi adanya korelasi kejadian diabetes melitus (new-onset diabetes mellitus/NODM) setelah inisiasi penggunaan statin. Mekanisme spesifik terkait pengaruh statin terhadap kejadian diabetes melitus masih belum sepenuhnya dipahami, namun gangguan fungsi sel beta pankreas melalui calcium channel blockade, berkurangnya sensitivitas jaringan terhadap insulin akibat berkurangnya ekspresi GLUT 4, rendahnya kadar adiponektin dan mungkin mekanisme lainnya diduga menjadi faktor pencetus NODM. Sebagaimana yang kita tahu, statin digunakan dalam terapi dislipidemia serta pencegahan baik primer maupun sekunder terhadap kejadian penyakit kardiovaskular melalui efek pleiotropiknya. Namun, dengan adanya keterkaitan kejadian NODM maka makna protektif penggunaan statin menjadi berkurang. Pada artikel ini akan dibahas mengenai kemungkinan mekanisme statin terkait kejadian NODM dan makna penggunaanya sebagai pencegahan penyakit kardiovaskular.
\end{abstract}

Kata kunci: statin, diabetes melitus, epidemiologi, dislipidemia, penyakit kardiovaskular

\author{
${ }^{1}$ Lulusan Prorgam Studi Profesi \\ Pendidikan Dokter, Fakultas \\ Kedokteran Universitas Trisakti, \\ Indonesia \\ ${ }^{2}$ Dokter Umum, RS Izza, \\ Cikampek, Jawa Barat, Indonesia \\ ${ }^{3}$ Departemen Ilmu Kesehatan \\ Masyarakat, Fakultas Kedokteran \\ Universitas Trisakti, Indonesia
}

\section{Korespondensi:}

Gede Bangun Sudrajad Lulusan Prorgam Studi Profesi Pendidikan Dokter, Fakultas Kedokteran Universitas Trisakti, Jalan Kyai Tapa, Kampus B, Grogol, Jakarta Barat 11440, Indonesia

Tlp: +6282114117490

Email: gedebangunsudrajad@ gmail.com

J Biomedika Kesehat 2020;3(2):101108

DOI: 10.18051/JBiomedKes.2020. v3.101-108

pISSN: 2621-539X / eISSN: 2621-5470

Artikel akses terbuka (open access) ini didistribusikan di bawah lisensi Creative Commons Attribution 4.0 International (CC-BY 4.0) 


\section{ABSTRACT}

\section{A new paradigm for statin: cardioprotective effect or induce new onset diabetes mellitus?}

3-Hydroxy-3-methylglutaryl coenzyme A (HMG-CoA) reductase inhibitors or commonly referred as statin, is a drug that has been used since 30 years ago and is one of the most often used drug for dyslipidemia. According to the latest results from many observational studies, randomized controlled trials (RCTs) and metaanalyzes have confirmed the correlation between the incidence of diabetes mellitus (new-onset diabetes mellitus/ NODM) after the initiation of statin use. Specific mechanisms related to the effect of statins on the incidence of diabetes mellitus are still not fully understood, but impaired beta pancreatic cell function through calcium channel blockade. It reduced tissue sensitivity to insulin due to reduced GLUT 4 expression, low levels of adiponectin and other mechanisms are thought to be the triggers for NODM. As we know, statins are used in the treatment of dyslipidemia and prevention of both primary and secondary cardiovascular disease events through pleiotropic effects. In the other hand the presence of NODM events will reduce the protective meaning of statin. This article will discuss the possible mechanism of statins that related to the incidence of NODM and the meaning of their use as prevention of cardiovascular disease.

Keywords: statins, diabetes mellitus, epidemiology, dyslipidemia, cardiovascular disease

\section{PENDAHULUAN}

Statin atau yang disebut juga sebagai 3-Hydroxy-3-methylglutaryl coenzyme A (HMGCoA) reductase inhibitors merupakan salah satu terapi farmakololgi yang paling sering digunakan di seluruh dunia. ${ }^{(1)}$ Statin berperan dalam menurunkan kadar kolesterol darah, dengan cara memblokade mekanisme pembentukan kolesterol di hati. (2) Secara luas statin juga digunakan sebagai terapi preventif secara primer maupun sekunder terhadap penyakit kardiovaskular karena menurunkan kadar kolesterol khususnya low density lipoprotein (LDL). Selai itu, statin juga memiliki efek pleirotropik untuk mengurangi inflamasi vaskuler, meningkatkan fungsi dari endotel, dan mengurangi pembentukan thrombus. $(3,4)$

Berdasarkan data epidemiologi, penyakit-penyakit paling sering muncul pada dekade terakhir ini menunjukan perubahan yang sangat signifikan, khususnya negara-negara yang berada di Kawasan Asia Pasifik. Penyakit noninfeksi menjadi penyebab utama kematian, terutama penyakit kardiovaskular. ${ }^{(5)}$ Beberapa studi prospektif menunjukan bahwa dislipidemia merupakan salah satu faktor independen penyebab penyakit kardiovaskular. ${ }^{(6)}$ Selain dislipidemia faktor konvensional lain yang memicu terjadinya penyakit kardiovaskular yaitu peningkatan tekanan darah (hipertensi), kebiasaan merokok dan juga diabetes melitus. ${ }^{7}$ Menurut data WHO, prevalensi dyslipidemia di Indonesia mencapai 36\% (33.1\% laki-laki dan $38.2 \%$ perempuan) serta prevalensi diabetes melitus sebesar $6.1 \%-17 \%$ pada pria dan 4.7\%-14.8\% pada wanita. ${ }^{(5,7)}$ Disinilah pentingnya penggunaan terapi farmakologis statin.

Baru-baru ini, selain manfaatnya terhadap penurunan kadar kolesterol, statin ternyata memiliki efek terhadap peningkatan kadar gula darah dan peningkatan risiko new onset diabetes mellitus (NODM). Terdapat studi observasional, meta-analyses dan RCTs yang telah dilakukan, menunjukkan risiko yang lebih tinggi terjadinya NODM adalah pada pasien yang mengonsumsi statin dibandingkan dengan mereka yang tidak mengonsumsi statin. ${ }^{(8)}$ Hasil studi sebelumnya memperlihatkan bahwa insiden NODM pada kelompok pengguna statin lebih tinggi dibandingkan dengan non pengguna statin (HR 1.88; 95\% CI, 1.85-1.93). ${ }^{(9)}$ Hasil studi yang lain juga memperlihatkan bahwa insiden NODM sebesar 1,709 individu (7.64\%) pada grup dengan statin (Hazard ratio [HR]: 1.66, 95\% confidence interval $[\mathrm{CI}]: 1.49$ to $1.85, \mathrm{p}<0.001){ }^{(10)}$

Adanya keterkaitan kejadian NODM pada pengguna statin maka makna protektif penggunaan statin menjadi berkurang. Pada artikel ini akan dibahas mengenai kemungkinan mekanisme statin terkait kejadian NODM dan makna penggunaanya sebagai pencegahan penyakit kardiovaskular yang diharapkan dapat menjadi referensi dalam bidang penelitian yang lebih lanjut.

\section{Statin dalam menurunkan kadar kolesterol}

Mekanisme kerja statin menghambat enzim HMG-CoA reduktase di hepar (hepatosit). (2,11) HMG-CoA reduktase (HMGCR) merupakan enzim yang berperan dalam sintesis kolesterol dan mengonversi 3-hydroxy-3-methylglutarylcoenzyme A (HMG-CoA) menjadi asam mevalonat 
(prekusor jalur de novo biosintesis kolesterol) melalui mekanisme four-electron reductive deacetylation. ${ }^{(11,12)}$ Statin secara reversible bersaing dengan substrat endogen, pada sisi aktif HMG-CoA reductase. Ikatan statin dengan sisi aktif akan menyebabkan penurunan fungsi enzim HMGCR yang pada akhirnya akan menurukan produksi kolesterol dan mengurangi cadangan kolesterol intraseluler di hepatosit. ${ }^{(1)}$ Peristiwa tersebut memicu meningkatnya ekspresi reseptor low density lipoprotein (LDL) di hepatosit, yang meningkatkan uptake LDL dan prekusor LDL dari sirkulasi sistemik. Padaakhirnya selain mengurangi biosintesis kolesterol, statin juga secara indirek meningkatkan pembersihan LDL di dalam plasma. Pada mekanisme sekunder statin menginduksi penurunan sintesis dari apolipoprotein B100 di hepar dan mengurangi sintesis dan sekresi dari triglyceride-rich lipoproteins. ${ }^{(12)}$

\section{Efek pleiotropik statin}

Studi menunjukkan statin memiliki efek pleiotropic yang memiliki manfaat preventif baik primer atau sekunder terhadap penyakit jantung koroner. ${ }^{(13)}$ Statin menghambat pembentukan asam mevalonat melalui efek inhibisi enzim HMG-CoA reduktase. Selain sebagai prekusor pembentukan kolesterol, asam mevalonat juga merupakan prekusor dari jalur isoprenoid. Kondisi ini menyebabkan hambatan sintesis essential isoprenoid intermediate seperti farnesyl pyrophosphate (FPP) dan geranylgeranyl pyrophosphate (GGPP). ${ }^{(14,15)}$

Sel endotel FPP dan GGPP adalah faktor independen aktifasi dan modifikasi dari protein $\mathrm{G}$ heterotrimerik yaitu Ras dan Ras-like protein seperti Rho, Rab, Rac, Ral, atau Rap. Rho dan Ras iniberfungsiuntuk meregulasi sel dalam proliferasi, diferensiasi, apoptosis dan fungsi sitoskleleton. $(14,15)$ Selain Rho dan Ras, Rac juga mampu mengaktifasi pembentukan nicotinamide adenine dinucleotide phosphate (NADPH) oxidase dan memproduksi reactive oxygen species (ROS) yang keduanya merupakan suatu oksidan berbahaya yang mampu mengoksidasi LDL (memicu proses atherogenic dan memediasi pembentukan foam cell), serta memiliki efek terhadap proliferasi sel miokard menjadi hipertrofi. ${ }^{(15)}$

Terdapat suatu protein serine/threonine yang memiliki efek terhadap sistem kardiovaskular dan berkontribusi dalam proses akhir Rho yang belakang disebut sebagai Rho Kinase (ROCKs). ROCKs akan aktif jika berikatan dengan Rho, berdasarkan penelitian dari model binatang, ROCKs memiliki efek remodeling patologis pada jantung berupa fibrosis dan apoptosis dari sel miokard. ${ }^{(16)}$ Selain itu, ROCKs juga meningkatkan proliferasi dan sintesis protein matriks ektra selular di sel otot polos pembuluh darah. ${ }^{(15)}$ Inaktifasi dari ROCKs yang secara tidak langsung disebabkan oleh statin menghasilkan stabilisasi mRna dari endothelium-derived nitric oxide synthase (eNOS) dan aktivasi kaskade $A k t / P 13 K$. Tingginya aktivitas dari eNOS menyebabkan peningkatan produksi dan bioavailabilitas Nitric Oxide (NO) dan juga meningkatkan proses neoangiogenesis. Peningkatan NO sendiri memiliki dampak terhadap vasodilatasi pembuluh darah, sehingga perfusi jaringan terjaga, mencegah agregasi platelet dengan menurunkan $\mathrm{b}$ thromboglobulin dan platelet faktor 4 , serta menekan proliferasi otot polos pembuluh darah. Yang terkahir, adanya protein kinase $A k t$ telah terbukti berhubungan dengan perbaikan metabolisme aerob miokard dan tingginya angiopoietin yang mempercepat proses angiogenesis. Lebih jauh lagi Akt juga menstimulasi aktivasi eNOS. ${ }^{(16,17)}$ Pada kesimpulannya, reduksi dan inaktifasi jalur isoprenoid menghasilkan efek multiple yaitu antiinflamasi, antioksidan, stabilisasi plak, antiproliferatif dan kardioprotektif. ${ }^{(15)}$

\section{Risiko NODM pada pengguna statin}

Dalambeberapastudiyang telahdilakukan, menunjukan risiko yang lebih tinggi terjadinya NODM pada seseorang yang mengonsumsi statin. $(8-10,18,19)$ Pada studi kohort sebelumnya, dengan jumlah sampel 1.034.982 yang dibagi menjadi 518.491 ditiap grup melalui propencity-scorematched analysis. Penelitian tersebut dilakukan selama rentang waktu 3.9 tahun, menunjukan insiden NODM pada grup pengguna statin lebih tinggi dibandingkan dengan non pengguna statin (HR 1.88; 95\% CI, 1.85-1.93). ${ }^{(9)}$ Studi kohort lainnya dengan jumlah subjek 40.164 orang dibagi menjadi 2 grup (22.366 pengguna statin dan 17.798 tidak menggunakan statin) dengan rerata rentang waktu studi sekitar 5.6 2.6 tahun untuk grup dengan statin dan 10.2 \pm 1.7 tahun untuk grup tanpa statin, menunjukan insiden NODM sebesar 


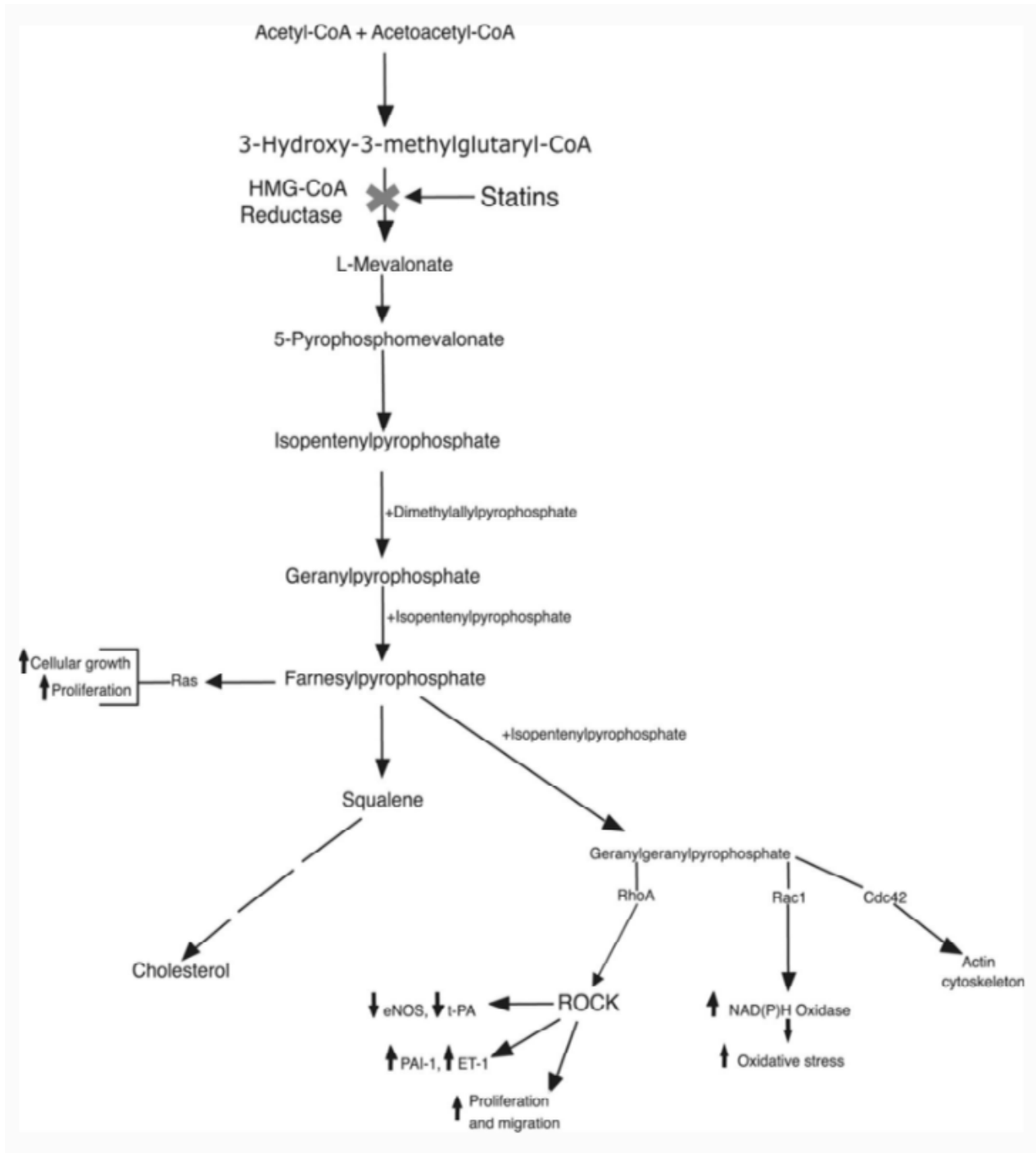

Gambar 1. Mekanisme statin menghambat jalur sintesis kolesterol dan isopreniodmelalui inhibisi dari HMG-CoA reduktase ${ }^{(15)}$

1.709 individu (7.64\%) pada grup dengan statin (HR 1.66; 95\% CI, 1.49-1.85, p<0.001). ${ }^{(10)}$

Pada studi JUPITER (randomized, double blind trial), dengan intervensi $20 \mathrm{mg}$ rosuvastatin vs. placebo dengan jumlah sampel 17.603 yang dibagi menjadi 2 grup. Pada grup dengan satu atau lebih faktor risiko diabetes $(n=11.508)$ menunjukkan terjadinya diabetes sebesar $28 \%$ (HR 1.28; 95\% CI, 1.07-1.54, $\mathrm{p}=0.01$ ) sedangkan pada grup tanpa faktor risiko $(\mathrm{n}=6.095)$ tidak menunjukan terjadinya diabetes melitus (HR $0.99,95 \%$ CI, 0.45-2.21, $\mathrm{p}=0.99) .{ }^{(18)}$ Studi lainnya menunjukkan subjek perempuan postmenopause yang berusia 50-79 tahun, dengan rerata rentang waktu 3 tahun, subjek berjumlah 153.840 orang ( $n=10.834$ grup statin dan $n=143.006$ grup non statin) menunjukkan grup dengan statin memiliki asosiasi yang lebih tinggi terhadap peningkatan risiko terjadinya diabetes melitus (HR 1.71; 95\% CI, 1.61-1.83), sehingga pada penelitian ini ditarik kesimpulan bahwa terapi statin pada kelompok wanita yang sudah menopause memiliki keterkaitan risiko terhadap terjadinya diabetes melitus. ${ }^{(19)}$

\section{Mekanisme NODM yang diinduksi statin}

Terdapatbeberapa mekanismeyang diduga mendasari terjadinya NODM di kalangan para pengguna statin, ${ }^{(8-10,18,19)}$ namun belum sepenuhnya dipahami. Baru-baru ini ditemukan sebuah bukti bahwa statin mempengaruhi sensitivitas jaringan terhadap insulin dan sekresi insulin oleh sel b. ${ }^{(20)}$ Dalam sebuah studi observasional terhadap 8000 subjek, penggunaan statin menyebabkan terjadinya peningkatan kadar glukosa darah, penurunan sensitivitas insulin rata-rata sebesar 


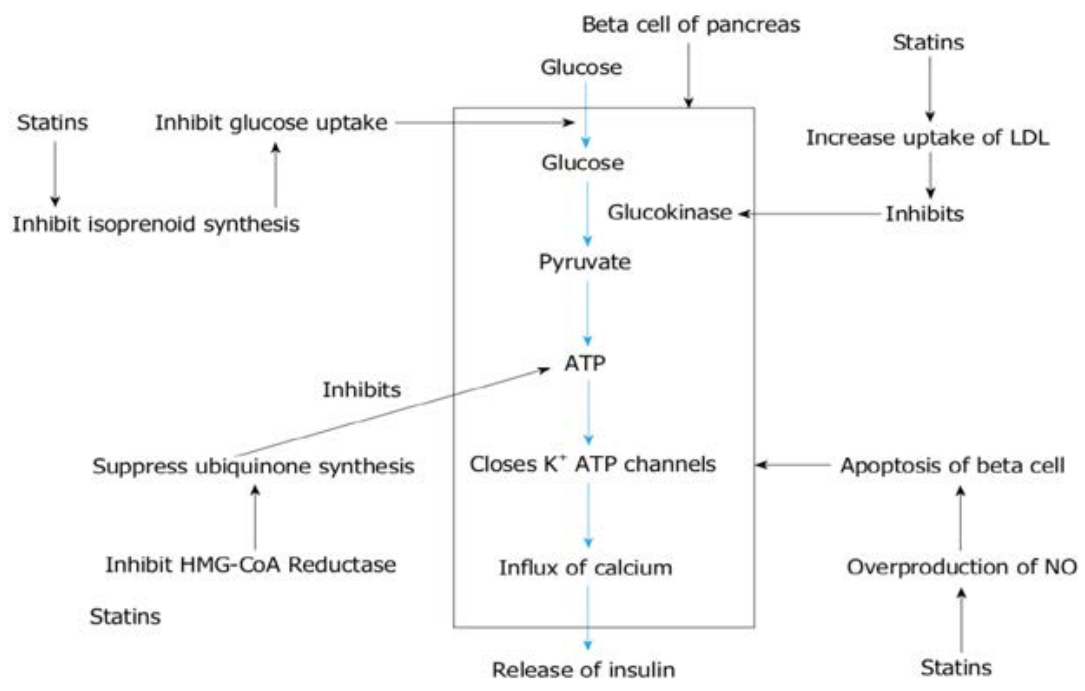

Gambar 2. Pengaruh statin terhadap sel $\beta$ pancreas $^{(24)}$

$24 \%$ dan penurunan kadar sekresi insulin ratarata sebesar $12 \%{ }^{(20)}$ Kondisi ini juga dibuktikan dengan adanya hasil penelitian experimental terhadap sel $\beta$ pancreas dan sel otot manusia. ${ }^{(21)}$ Pada penelitian tersebut diketahui bahwa empat jenis statin (atorvastatin, pravastatin, rosuvastatin dan pitavastatin) menurunkan viabilitas ratarata sel $\beta$ pancreas $(32.12 \%, 41.09 \%, 33.96 \%$, dan 29.19\%) diduga dikarenakan efek sitotoksik dan efek penghentian fase $G_{0} G_{1}$ sel b selama siklus pembelahan sel. Penelitian tersebut juga menemukan bahwa sel $\beta$ setelah 24 jam pemberian statin (atorvastatin, pravastatin, rosuvastatin dan pitavastatin) mengalami penurunan sekresi insulin rata-rata $(34.07 \%, 30.06 \%, 26.78 \%$ dan $19.22 \%)$. Respon sekresi insulin oleh sel $\beta$ selama kondisi hiperglikemi menurun di mana dibutuhkan kadar glukosa yang tinggi yaitu $28 \mathrm{mmol} / \mathrm{L}$ jika dibandingkan dengan kadar fisiologis (5.6mmol/L) untuk memicu respon sel $\beta$ dalam mensekresi insulin. Keadaan ini dikaitkan dengan temuan adanya penurunan ekspresi GLUT-2 dan ekspresi berlebihan p-p38 MAPK pada sel b selama pemberian statin. Selain efek terhadap sel $\beta$, dari penelitian ini juga diperoleh hasil di mana ekspresi dari GLUT-4 pada HSkMC mengalami penekanan yang berdampak pada penurunan penggunaan glukosa. ${ }^{(21)}$

Terdapat banyak kemungkinan diabetogenic penggunaan statin, seperti berkurangnya pembentukan adiponektin dan leptin oleh sel adiposit, penurunan sintesis ubiquinone $\mathrm{CoQ}_{10}$ pada mitokondria, reduksi uncoupling protein 3 (UCP3), disregulasi microRNA(miRNA) serta perubahan ukuran partikel lipoprotein (reduksi ukuran LDL-C, HDL-C dan peningkatan ukuran VLDL-C). ${ }^{(1,22,23)}$

Terdapat beberapa hal yang menyatakan bahwa statin menjadi penyebab NODM melalui mekanisme resistensi insulin di jaringan. Pertama melalui penurunan fosforilasi insulin receptor substrate-1 (IRS-1) dan regulatornya RhoA. Kedua, penurunan translokasi GLUT-4 ke membran sel dan Rab4 (protein G dalam proses translokasi GLUT-4). Ketiga, adanya penekanan pembentukan protein membrane caveolin-1. ${ }^{(22,23)}$ Keempat melalui proses hambatan sekresi insulin diduga mendasari terjadinya NODM akibat peningkatan influks kolesterol LDL ke dalam sel $\beta$ yang menghambat aktivitas glucokinase serta mengganggu metabolisme glukosa dan pememblokiran L-type $\mathrm{Ca}^{2+}$ channel pada sel $\beta .^{(1,22,23)}$

Keuntungan fisiologis dari penggunaan statin saat ini bahkan dihipotesiskan berperan dalam proses patologis terjadinya diabetes, meliputi peningkatan produksi NO terkait penggunaan statin (fungsi protektif endotel) merangsang proses apoptosis sel melalui aktivasi calcium-dependent protease calpain, peningkatan penyerapan LDL-plasma dalam hal ini LDL teroksidasi ke dalam sel $\beta$ pancreas akibat penurunan sintesis de novo LDL dan peningkatan reseptor LDL sel $\beta$ merangsang proses destruksi sel dengan menginduksi aktivasi sistem imun dan mempercepat proses apoptosis sel. ${ }^{(22,23)}$ 


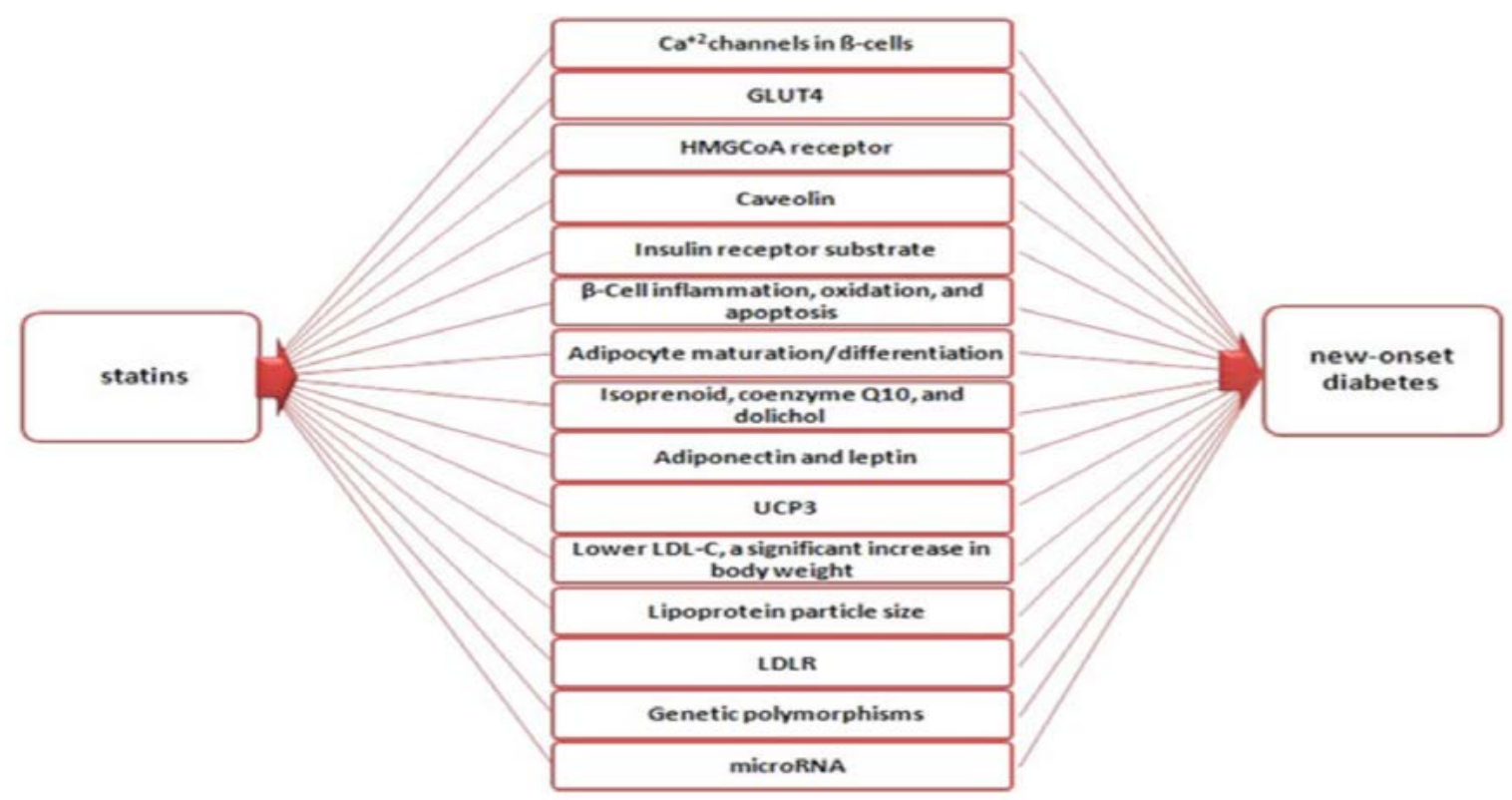

Gambar 3. Mekanisme onset baru diabetes melitus yang diinduksi statin. ${ }^{(23)}$

\section{Efek kardioprotektif atau penyebab onset baru diabetes melitus?}

American Heart Association (AHA) telah mengeluarkan pernyataan ilmiah bahwa penggunaan statin hanya menimbulkan risiko minimal $(0.2 \%$ per tahun $)$ mengenai kejadian NODM dan bahkan kejadiannya lebih dominan kepada pengguna statin yang sudah memiliki faktor risiko diabetes. Tedapat studi yang menyatakan bahwa statin memang meningkatkan risiko NODM sejalan dengan kepatuhan penggunaan obat ini (14.8 kasus NODM tiap 1000 orang/tahun). Namun, perlu digarisbawahi bahwa penurunan risiko kejadian penyakit kardiovaskular pada pasien NODM sejalan dengan meningkatnya kepatuhan penggunaan statin dari HR 70\% $95 \%$ CI: $18 \%-44 \%$ ) hingga menjadi HR 10\% (95\% CI: -60\%-180\%). Dalam studi lain terhadap 32.572 subjek yang diikuti selama 4.9 tahun terapi statin, diperoleh 2 kasus NODM per 1000 orang/tahun juga 6.5 kejadian penyakit kardiovaskular per 1000 orang/tahun yang berhasil dicegah. Hasil meta analisis dari $13 \mathrm{RCT}$ diperoleh bahwa statin menginduksi 1 kejadian NODM dan dalam waktu yang bersamaan memproteksi 9 kejadian penyakit kardiovaskular (9:1 keuntungan vs risiko). ${ }^{(25-27)}$

Berdasarkan pernyataan dari studi yang disampaikan sebelumnya, saat ini harus dilakukan penilaian terlebih dahulu terhadap manfaat dan risiko pemberian terapi statin kepada pasien terutama yang berisiko rendah mengalami penyakit kardiovaskular serta tidak mencegah penggunaan statin pada pasien dengan risiko kejadian penyakit kardiovaskular yang tinggi. Jadi meskipun pasien memiliki indikasi kuat pemberian statin, perlu adanya pertimbangan lebih lanjut terkait dosis yang akan diberikan, dan disarankan memulai dari dosis rendah, karena telah banyak studi yang mengonfirmasi adanya hubungan yang erat antara dosis penggunaan statin dengan NODM. ${ }^{(20,21)}$

Pada kondisi upaya preventif primer dengan risiko sedang sampai tinggi dan preventif sekunder terhadap penyakit kardiovaskular jelas statin harus menjadi terapi pilihan utama, walaupun pada pasien lansia atau orang dengan prediabetes, resisten insulin dan sindroma metabolik. Mengacu pada studi sebelumnya, ${ }^{(25,26,27)}$ selama penggunaan statin perlu adanya pemantauan kadar glukosa darah rutin serta intervensi gaya hidup berupa pengawasan terhadap penurunan berat badan, pola diet dan aktivitas fisik.

Studi terhadap 27.000 subjek selama 10 tahun mendapatkan para pengguna statin cenderung memiliki jumlah asupan kalori dan masa lemak yang berlebih jika dibandingkan dengan yang tidak menggunakan statin. Studi lainnya oleh The Diabetes Prevention Program Research Group dengan intervensi intensif gaya hidup (diet rendah kalori, rendah lemak serta aktivitas fisik 150 menit per minggu) dapat mengurangi terjadinya insiden DM 58\% selama 2.8 tahun dibanding kelompok dengan tanpa 
intervensi. Namun bagaimana dengan seseorang dengan risiko rendah terhadap terapi statin? Dalam kelompok dimana manfaat statin pada pengurangan risiko kardiovaskular kurang kuat (misalnya, kelompok pencegahan primer berisiko rendah tanpa peningkatan yang signifikan kadar LDL-C), agar lebih hati-hati menggunakan terapi statin. Jika statin digunakan dalam kelompok berisiko rendah dengan peningkatan kadar LDL-C yang sedang, penggunaan statin harus dibatasi dan pemantauan terhadap kadar gula darah harus dilakukan secara rutin. ${ }^{(20,24,28)}$

\section{KESIMPULAN}

Meskipun, beberapa studi terakhir menunjukkan kaitannya terhadap insiden diabetes melitus, statin tetap menjadi pilihan terapi terhadap penyakit kardiovaskular sebagai terapi preventif primer maupun sekunder karena efek pleiotropiknya. Hal yang menjadi kunci terhadap adverse effect ini adalah monitoring kadar glukosa darah serta edukasi mengenai pola hidup sehat dan aktivitas fisik yang cukup.

\section{REFERENSI}

1. Aiman U, Najmi A, Khan RA. Statin induced diabetes and its clinical implication. J Pharmacol Pharmacother. 2014; 5(3):181-5. doi: 10.4103/0976-500X.136097

2. Agisha PR. Statin Induced Diabetes [Internet]. IJSR. 2017 [cited 2020 Feb 2]; 6(6):886-8 Available from: https://www.ijsr.net/search index_results_paperid.php?id=ART20174158

3. Chrysant SG. New Onset Diabetes Mellitus Induced by Statin: Current evidence. Postgrad Med. 2017; 129:430-5. doi: 10.1080/00325481.2017.1292107

4. Thakker D, Nair S, Pagada A, et al. Statin use and the risk of developing diabetes: a network metaanalysis. Pharmacoepidemiol Drug Saf. 2016; 25(10): 1131-1149. doi: 10.1002/pds.4020

5. Lin CF, Chang YH, Chien SC, et al. Epidemiology of Dyslipidemia in the Asia Pacific Region. Int J Gerontol. 2018; 12: 2-6. doi:10.1016/j. ijge.2018.02.010

6. Liu X, Yu S, Mao Z, et al. Dyslipidemia prevalence, awareness, treatment, control, and risk factors in Chinese rural population: the Henan rural cohort study. Lipids Health Dis. 2018; 17(1):119. doi:10.1186/s12944-018-0768-7

7. Nguyen HN, Fujiyoshi A, Abbott $R$, et al. Epidemiology of cardiovascular Risk Factors in Asian Countries. Circ J. 2013; 77(12): 2851-9. doi:10.1253/circj.cj-13-1292

8. Kim J, Lee HS, Lee KY. Effect of statin on fasting glucose in non-diabetic individuals: nationwide population-based health examination in Korea. Cardiovasc Diabetol. 2018;17(1):155. doi:10.1186/ s12933-018-0799-4

9. Ko MJ, Jo AJ, Kang SH, et al. Time and Dose Dependent Association of Statin Use with Risk of Clinically Relevant New Onset Diabetes Mellitus in Primary Prevention: A nationwide Observational Cohort Study. J Am Heart Assoc. 2019;8(8):e011320. doi:10.1161/ JAHA.118.011320

10. Lee SE, Sung JM, Cho IJ, et al. Risk of new onset diabetes among patients treated with statins according to hypertension and gender: Results from a nationwide health screening cohort. PLoS One. 2018; 13(4): e0195459. doi: 10.1371/journal. pone. 0195459

11. Davies JT, Delfino SF, Feinberg CE, et al. Current and Emerging Uses of Statin in Clinical Therapeutics: A Review. Lipid Insights. 2016; 9:13-29. doi: 10.4137/LPI.S37450

12. McFarland AJ, Dukie SA, Arora DS, et al. Molecular Mechanisms Underlying the Effects of Statins in the Central Nervous System. Int J Mol Sci. 2014; 15(11): 20607-37. doi:10.3390/ ijms 151120607

13. Liao JK, Laufs U. Pleiotropic Effect of Statins. Annu Rev Pharmacol Toxicol. 2009; 45:89-118. doi:10.1146/annurev.pharmtox.45.120403.095748.

14. Kavalipati N, Shah J, Ramakrishan A, et al. Pleiotropic effect of Statins. Indian J Endocrinol Metab. 2015; 19(5): 554-62. doi:10.4103/22308210.163106

15. Oesterle A, Laufs U, Liao JK. Pleiotropic Effect of Statin on the Cardiovascular System. Circ Res. 2017; 120(1): 229-243. doi:10.1161/ CIRCRESAHA.116.308537

16. OesterleA, Liao JK. The Pleiotropic Effects of Statin from Coronary Artery Disease and Stroke to Atrial Fibrillation and Ventricular Tachyarrhythmia. Curr Vasc Pharmacol. 2019;17(3):222-232. doi:10.2174 /1570161116666180817155058

17. Rohilla A, Rohilla S, Kumar A, et al. Pleiotropic Effects of Statin: A Boulevard to Cardioprotection. Arabian Journal of Chemistry. 2016; 9: S21-S27. doi:10.1016/j.arabjc.2011.06.025

18. Ridker PM, Pradhan A, MAcFadyen JG, et al. Cardiovascular benefit and diabetes risk of statin therapy in primary prevention: an analysis from the JUPITER trial. Lancet. 2012; 380(9841): 56571. doi:10.1016/S0140-6736(12)61190-8

19. Culver AL, Ockene IS, Balasubramanian R, et al. Statin Use and Risk of Diabetes Mellitus in Postmenopausal Women in the Women's Health Initiative. Arch Intern Med. 2012; 172(2): 144-52. doi: 10.1001/archinternmed.2011.625

20. Ganda OP. Statin-Induced Diabetes: Incidence, Mechanisms and Implications. F1000Res. 2016; 5: F1000 Faculty Rev-1499. doi: 10.12688/ f1000research.8629.1

21. Zhao W, Zhao SP. Different Effect of Statin on Induction of Diabetes Mellitus: An Experimental Study. Drug Des Devel Ther. 2015;9:6211-23. doi: 10.2147/DDDT.S87979

22. Sampson UK, Linton MF, Fazio S. Are Statins Diabetogenic?.CurrOpin Cardiol.2011;26(4):3427. doi: 10.1097/HCO.0b013e3283470359

23. Paseban M, Butler AE, Sahebkar A. Mechanisms of Statin-Induced New-Onset Diabetes. J Cell Physiol.2019; 234(8):12551-12561. doi: 10.1002/ jcp. 28123

24. Chogtu B, Magazine R, Bairy KL. Statin use and risk of diabetes mellitus. World J Diabetes. 2015; 6(2): 352-7. doi: 10.4239/wjd.v6.i2.352

25. Marvel FA, Blumenthal RS. AHA's Statement on The Safety Profile of Statin: Big Benefit with 
Low Risk [Internet]. AHA. 2018 [cited $2020 \mathrm{Feb}$ 2]. Available from: https://professional.heart.org/ professional/ScienceNews/UCM 503181 AHAsStatement-on-the-Safety-Profile-of-Statins-BigBenefit-with-Low-Risk.jsp

26. Corrao G, Compagnoni MM, Rea F, et al. Clinical Significance of Diabetes Likely Induced by Statin: Evidence from a Large Population-Based Cohort. Diabetes Res Clin Pract.2017;133:60-68. doi: 10.1016/j.diabres.2017.08.008

27. Sattar N, Taskinen MR.Statins are Diabetogenic-Myth or Reality?.Atheroscler Suppl. 2012;13(1):110. doi: 10.1016/j.atherosclerosissup.2012.06.001

28. Rocco MB. Statin and diabetes risk: Fact, fiction, and clinical implication. Cleve Clin J Med. 2012; 79(12): 883-89. doi: 10.3949/ccjm.79a.12091 